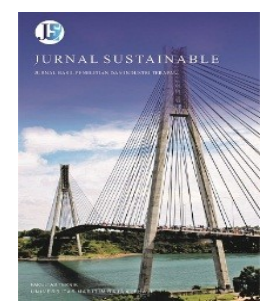

Jurnal Sustainable: Jurnal Hasil Penelitian dan Industri Terapan Vol. 09, No. 02, hal. 89-93, Oktober 2020

Jurnal Sustainable: Jurnal Hasil Penelitian dan Industri Terapan

ISSN 2615-6334 (Online) ISSN 2087-5347 (Print)

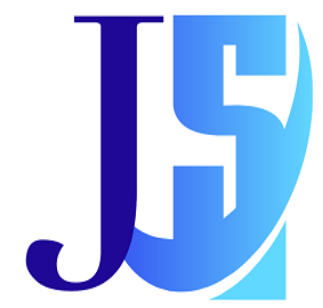

\title{
Prototipe Pemisah Minyak dan Air
}

\author{
Eko Prayetno $^{1, *}$, Tonny Suhendra ${ }^{2}$, Sugianto $^{3}$ \\ ${ }^{1,2,3}$ Jurusan Teknik Elektro, Fakultas Teknik, Universitas Maritim Raja Ali Haji \\ ${ }_{1,2,3} \mathrm{Jl}$. Politeknik Senggarang, Tanjungpinang 29100 \\ *Corresponding Author: ekoprayetno@umrah.ac.id
}

\begin{abstract}
One of the pollution that occurs is waste oil. Waste oil can cause damage to marine ecosystems, such as living things in polluted areas. In general, oil pollution is not handled directly, causing sustainable environmental damage. The purpose of this research is to detect waste oil and separate the oil and water by filtering it. This research uses the help of the Arduino uno device for photodiode input, control of the relay to activate the pump and the LED as a pump indicator. The overall test results are calculated as an average. A $1000 \mathrm{ml}$ amount of oil was needed with an average time of 11.8 minutes, with a total average total separation of $1142 \mathrm{ml}$, consisting of an average of $742 \mathrm{ml}$ of oil and $400 \mathrm{ml}$ of water. Testing with an amount of $1500 \mathrm{ml}$ of oil is required with an average time of 19.2 minutes, with a total average total separation of $1660 \mathrm{ml}$, consisting of an average of $1260 \mathrm{ml}$ of oil and $400 \mathrm{ml}$ of water. Tests with $2000 \mathrm{ml}$ of oil required an average time of 23 minutes, with a total average total separation of $2164 \mathrm{ml}$, consisting of an average of $1740 \mathrm{ml}$ of oil and $444 \mathrm{ml}$ of water. Testing with an amount of $2500 \mathrm{ml}$ of oil is required with an average time of 32.6 minutes, with a total average total separation of $2812 \mathrm{ml}$, consisting of an average of $2214 \mathrm{ml}$ of oil and $598 \mathrm{ml}$ of water.
\end{abstract}

Keywords - Waste Oil, Arduino Uno, IR LED, Photodiode, Relay.

Intisari- Salah satu pencemaran yang terjadi yaitu limbah minyak. Limbah minyak bisa menyebabkan kerusakan ekosistem laut, seperti makhluk hidup yang berada di wilayah pencemaran. Pada umumnya pencemaran minyak tidak ditangani secara langsung, sehingga menyebabkan kerusakan lingkungan secara berkelanjutan. Tujuan penelitian ini adalah mendeteksi limbah minyak dan memisahkan antara minyak dan air dengan cara penyaringan. Penelitian ini menggunakan bantuan perangkat Arduino uno untuk input photodioda, kontrol pada relay untuk mengaktikan pompa dan LED sebagai indikator pompa. Hasil pengujian keseluruhan dihitung dengan angka rata-rata. Jumlah minyak $1000 \mathrm{ml}$ dibutuhkan dengan ratarata waktu selama 11,8 menit, dengan total rata-rata pemisahan keseluruhan sebanyak $1142 \mathrm{ml}$, terdiri dari rata-rata $742 \mathrm{ml}$ minyak dan $400 \mathrm{ml}$ air. Pengujian dengan jumlah minyak $1500 \mathrm{ml}$ dibutuhkan dengan rata-rata waktu selama 19,2 menit, dengan total rata-rata pemisahan keseluruhan sebanyak $1660 \mathrm{ml}$, terdiri dari rata-rata $1260 \mathrm{ml}$ minyak dan $400 \mathrm{ml}$ air. Pengujian dengan jumlah minyak $2000 \mathrm{ml}$ dibutuhkan dengan rata-rata waktu selama 23 menit, dengan total rata-rata pemisahan keseluruhan sebanyak $2164 \mathrm{ml}$, terdiri dari rata-rata $1740 \mathrm{ml}$ minyak dan $444 \mathrm{ml}$ air. Pengujian dengan jumlah minyak $2500 \mathrm{ml}$ dibutuhkan dengan ratarata waktu selama 32,6 menit, dengan total rata-rata pemisahan keseluruhan sebanyak $2812 \mathrm{ml}$, terdiri dari rata-rata $2214 \mathrm{ml}$ minyak dan $598 \mathrm{ml}$ air.

Kata kunci- Limbah Minyak, Arduino Uno, IR LED, Photodioda, Relay 


\section{Pendahuluan}

Kerusakan dan kerugian yang di sebabkan oleh pencemaran minyak seperti di kepulauan seribu yaitu sebanyak 20 budi daya ikan kerapu mengalami kerugian, 60 budi daya rumput mengalami kerugian, 100 kelompok nelayan mengalami kerugian, ekositem mangrove rusak sekitar 7,7 hektar, berkurangnya penyu sisik yang bertelur di pantai sekitar 50\%, ditemukan 905 biji telur penyu sisik yang tidak berembrio [3].

Permasalahan Limbah Minyak (Sludge Oil) juga sering terjadi di daerah Kabupaten Bintan, sehingga hampir seluruh daerah pesisir pantai pulau bintan tercemar. Limbah minyak ini berasal dari kapal-kapal yang melewati perairan Internasional yang berhadapan langsung dengan teritorial Kabupaten Bintan, sehingga di saat musim utara limbah tersebut akan terbawa arus masuk ke perairan Kabupaten Bintan yang berbatasan langsung [9].

Pencemaran tersebut dapat memberikan pengaruh yang membahayakan terhadap ekosistem laut. Limbah minyak merupakan Bahan Berbahaya dan Beracun (B3), karena baik sifat, konsentrasi maupun jumlahnya dapat mencemari dan membahayakan lingkungan hidup, serta kelangsungan makhluk hidup yang ada di muka bumi ini, termasuk manusia. Salah satu akibat yang ditimbulkan yaitu terhambatnya pertumbuhan fitoplankton laut akibat keberadaan senyawa beracun dalam komponen minyak bumi. Jika jumlah pitoplankton menurun, maka populasi ikan, udang, dan kerang juga akan menurun sehingga rantai makanan akan terputus [8].

Banyak dampak buruk akibat pencemaran limbah minyak, dan masalah ini sangat penting untuk ditangani. Berdasarkan permasalahan tersebut, peneliti mencoba untuk membuat sebuah prototipe alat pemisah minyak dan air, dimana alat ini diharapkan bisa mengatasi pencemaran yang di akibatkan oleh pencemaran limbah minyak dan dapat mengurangi kerusakan ekosistem.

\section{II. KAJIAN LITERATUR}

Penelitian terdahulu merupakan salah satu referensi yang diperlukan oleh penulis dalam menyelesaikan tulisan agar lebih optimal. Ada beberapa kajian penelitian yang sudah dilakukan peneliti sebelumnya mengenai prototipe pemisah minyak dan air, diantaranya pernah dilakukan oleh [1] dengan judul "rancang bangun alat pemisah minyak pelumas (oli) dengan air secara otomatis pada limbah perbengkelan". Penelitian ini dibuat untuk membersihkan limbah selokan yang tercampur dengan oli dengan cara membuat pemisah oli dengan air secara otomatis menggunakan valve solenoid. Prinsip kerja dari alat ini apabila sinar laser masih menyinari LDR, maka LDR akan mengirimkan sinyal ke arduino untuk membuka valve solenoid. Hal ini menandakan bahwa masih ada air pada bak penampung. Apabila sinar laser tertutup oleh oli maka LDR akan mengirimkan sinyal untuk mematikan relay. Selanjutnya relay akan memutuskan tegangan ke selenoid valve untuk menutup selenoid valve. Dari pengujian kerja valve solenoid pada saat air yang telah terpisahkan sebanyak $100 \mathrm{ml}$ katup solenoid akan membuka selama 13 menit dan ketika air yang tercampur oli sebanyak $200 \mathrm{ml}$ maka valve solenoid akan membuka selama 21 menit.

Penelitian selanjutnya [3] dengan judul "efisiensi penggunaan oil water separator pada kapal penangkap ikan untuk pencegahan pencemaran minyak di laut (studi kasus $\mathrm{km}$. mantis) di bbppi semarang". Penelitian ini bertujuan untuk mengetahui efisiensi penggunaan OWS, dan perbedaan toksisitas minyak sebelum dan setelah diolah dengan OWS terhadap Chlorella vulgaris. Metode yang digunakan adalah eksperimental laboratorium dengan menganalisis kandungan minyak, dilanjutkan analisis efisiensi OWS dan uji toksisitas minyak terhadap alga Chlorella vulgaris sebelum dan setelah diolah dengan OWS. Kemudian dilakukan uji statistika T berpasangan apabila distribusi data normal dan uji wilcoxon apabila distribusi data tidak normal dengan taraf signifikansi 95\%. Hasil penelitian menunjukkan OWS mampu mereduksi kandungan minyak dari sebelum diolah dengan OWS antara $2.083,60 \mathrm{mg} / \mathrm{L}-29.246,60 \mathrm{mg} / \mathrm{L}$ menjadi $8,40 \mathrm{mg} / \mathrm{L}$ - 23,20 mg/L setelah diolah, tingkat efisiensi mencapai 99,3\% - 99,9\%. Hasil analisis statistik uji wilcoxon pada hasil uji toksisitas $(\mathrm{p}<0,05)$ OWS mampu mengurangi toksisitas limbah cair kamar mesin mengandung minyak sebelum dan setelah diolah dengan OWS terhadap Chlorella vulgaris.

Penelitian selanjutnya [2] dengan judul "pengaruh pencemaran minyak di laut terhadat ekosistem laut". Tujuan dari penelitian ini adalah menyadari akan besarnya bahaya pencemaran minyak di laut. Pembahasan yang didapatkan bahwa pengaruh yang didapatkan oleh pemcemaran minyak dilaut yaitu seperti Kerusakan dan kerugian yang di sebabkan oleh pencemaran minyak seperti di kepulauan seribu yaitu sebanyak 20 budi daya ikan kerapu mengalami kerugian, 60 budi daya rumput mengalami kerugian, 100 kelompok nelayan 
mengalami kerugian, ekositem mangrove rusak sekitar 7,7 hektar, berkurangya penyu sisik yang bertelur di pantai sekitar 50\%, ditemukan 905 biji telur penyu sisik yang tidak berembrio.

Penelitian selanjutnya [4] dengan judul "pemodelan tumpahan minyak di perairan teluk lampung". Tujuan dari penelitian adalah untuk mengetahui sebaran tumpahan minyak jenis bensin dan diesel di Perairan Teluk Lampung. Metode penelitian menggunakan metode kuantitatif. Tahapan penelitian ini yaitu pengukuran data lapangan, pemodelan hidrodinamika dan pemodelan tumpahan minyak. Penentuan lokasi penelitian menggunakan metode purposive sampling. Hasil simulasi model hidrodinamika pola kecepatan arus di perairan Teluk Lampung bergerak secara bolakbalik mengikuti periode pasang dan surut. Berdasarkan hasil penelitian dapat disimpulkan bahwa sebaran minyak jenis bensin dan diesel mengikuti pola arus. Sebaran tumpahan minyak jenis diesel lebih jauh penyebarannya serta waktu pemaparannya dibandingkan sebaran tumpahan minyak jenis bensin, hal ini dikarenakan minyak jenis bensin lebih cepat menguap dan terdegradasi dibandingkan minyak jenis diesel.

\section{METODE PENELITIAN}

Peneltitian ini dimulai dengan mengidentifikasi masalah. Rumusan masalah yang telah diperoleh dikumpulkan dan dibagi sesuai bagiannya masing- masing. Setelah itu dilakukan pencarian literatur dan pengumpulan data yang sesuai dengan rumusan masalah. Kajian literatur diperoleh dari internet berupa jurnal-jurnal penelitian sebelumnya yang berkaitan dengan perancangan.

Perancangan prototipe akan disesuaikan dengan rumusan masalah, kajian literatur, dan pengumpulan data yang telah didapat sebelumnya. Setelah perancangan prototipe pemisah minyak dan air, perangkat akan diuji coba. Uji coba ini bertujuan untuk mengetahui apakah perancangan perangkat bekerja sesuai yang diharapkan atau tidak. Jika perangkat tidak bekerja sesuai yang diharapkan maka akan dilakukan perancangan perangkat kembali hingga perangkat bekerja sesuai yang diharapkan.

Pada penelitian ini peneliti merancang perangkat berbentuk persegi panjang dengan ukuran panjang $40 \mathrm{~cm}$, lebar $28 \mathrm{~cm}$ dan tinggi bak $22 \mathrm{~cm}$. Sekat dibuat dengan ukuran tinggi $15 \mathrm{~cm}$ dan lebar $4 \mathrm{~cm}$, di bagian dasar sekat di buat saluran kecil dengan ukuran luas $8 \mathrm{~cm}$. Jenis pompa yang digunakan dalam perangkat ini yaitu pompa
DC $12 \mathrm{~V}$ dengan arus $350 \mathrm{~mA}$ dan laju aliran maksimum pompa $280 \mathrm{~L} / \mathrm{jam}$.

Desain perangkat prototipe pemisah minyak dan air dapat dilihat pada Gambar 1.

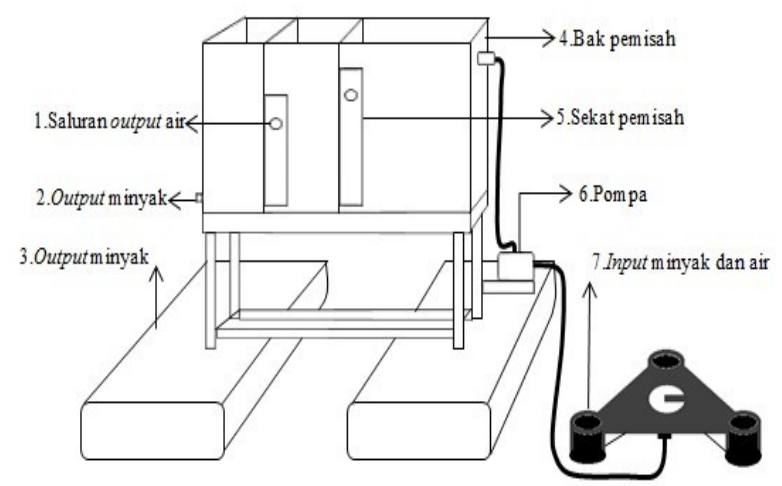

Gambar 1. Desain prototipe pemisah minyak dan air

Prinsip kerja perangkat yaitu berdasarkan dari hasil deteksi sensor, pompa dalam kondisi tidak bekerja ketika sensor tidak mendeteksi minyak dan pompa bekerja ketika sensor mendeteksi adanya minyak, ketika sensor mendeteksi adanya minyak pompa lansung memompa minyak yang ada di permukaan air ke dalam bak pemisah.bak pemisah terdiri dari 3 tahapan , pada tahap pertama minyak dan air akan dialirkan, Setelah minyak mencapai kesaluran yang dibuat, pada saat bersamaan minyak akan mengalir ke tahap pemisahan ke dua.

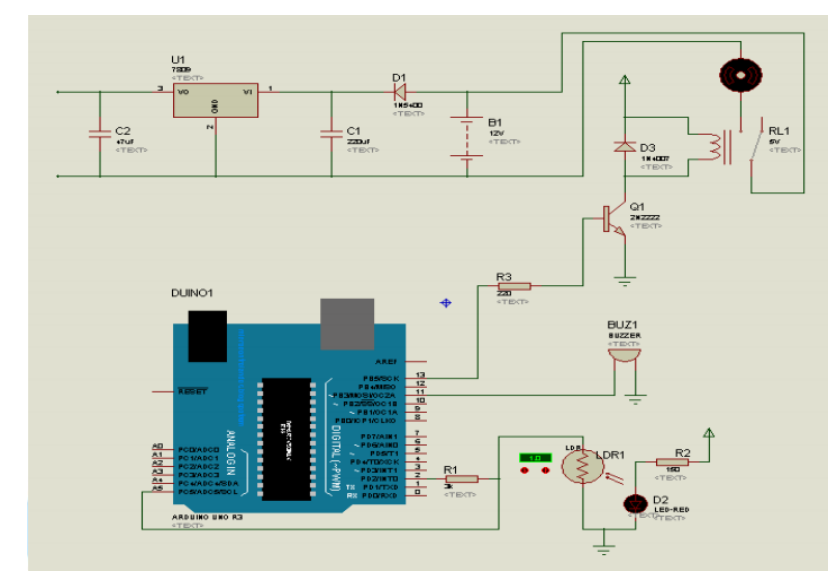

Gambar 2. Rangkaian perangkat secara keseluruhan

Air yang berada di posisi bawah minyak, akan mengalir ke sekat pemisah dan keluar melalui keluaran air yang dibuat. Pada tahap kedua minyak sudah banyak terpisah dari air, maka volume minyak akan lebih banyak dari air. Setelah minyak 
mencapai ke saluran, minyak akan mengalir ke tahap ke tiga dimana di tahap ketiga hasil minyak yang dipisahkan lansung mengalir ke wadah yang sudah disediakan. Rangkaian perangkat secara keseluruhan dapat dilihat pada Gambar 2.

Penelitian ini menggunakan mini komputer yang disebut arduino uno yang memiliki fitur 14 pin digital (6 pin dapat digunakan sebagai output PWM), 6 input analog, sebuah koneksi USB dan sebuah konektor sumber tegangan. Input akan diproses pada arduino uno dan memerintahkan output untuk menjalankan program. Pada prototype pemisah minak dan air menggunakan 6 pin pada arduino uno yang terdiri dari 2 pin digital dan 1 pin analog yaitu pin 2 yang digunakan untuk input photodioda, pin 13 digunakan sebagai kontrol pada relay untuk mengaktikan pompa dan LED sebagai indikator pompa. Semua perangkat sistem yang digunakan terhubung pada arduino uno

\section{Hasil dan Analisis}

Berdasarkan hasil pengujian, sistem dapat bekerja sesuai tujuan dari penelitian. Pengujian keseluruhan (Tabel 1) dihitung dengan angka ratarata. Jumlah minyak $1000 \mathrm{ml}$ dibutuhkan dengan rata-rata waktu selama 11,8 menit, Dengan total rata- rata pemisahan keseluruhan sebanyak $1142 \mathrm{ml}$, terdiri dari rata-rata $742 \mathrm{ml}$ minyak dan $400 \mathrm{ml}$ air. Pengujian dengan jumlah minyak $1500 \mathrm{ml}$ dibutuhkan dengan rata-rata waktu selama 19,2 menit, Dengan total rata-rata pemisahan keseluruhan sebanyak $1660 \mathrm{ml}$, terdiri dari rata-rata $1260 \mathrm{ml}$ minyak dan $400 \mathrm{ml}$ air.

Tabel 1. Hasil pengujian perangkat

\begin{tabular}{ccccc}
\hline $\begin{array}{c}\text { Jumlahminyak } \\
(\mathrm{ml})\end{array}$ & $\begin{array}{c}\text { Waktupengujian } \\
\text { (menit) }\end{array}$ & $\begin{array}{c}\text { Hasil pemisahan } \\
(\mathrm{ml})\end{array}$ & $\begin{array}{c}\text { Minyak } \\
(\mathrm{ml})\end{array}$ & $\begin{array}{c}\text { Air } \\
(\mathrm{ml})\end{array}$ \\
\hline \multirow{4}{*}{1000} & 12 & 1130 & 760 & 370 \\
& 10 & 1100 & 740 & 360 \\
& 13 & 1150 & 750 & 400 \\
& 13 & 1200 & 760 & 440 \\
& 11 & 1130 & 700 & 430 \\
\hline \multirow{3}{*}{1500} & 18 & 1650 & 1250 & 400 \\
& 21 & 1700 & 1200 & 500 \\
& 18 & 1650 & 1300 & 350 \\
& 20 & 1700 & 1300 & 400 \\
& 19 & 1600 & 1250 & 350 \\
\hline \multirow{5}{*}{2000} & 23 & 2120 & 1750 & 470 \\
& 25 & 2300 & 1800 & 500 \\
& 22 & 2000 & 1700 & 300 \\
& 24 & 2300 & 1750 & 550 \\
& 21 & 2100 & 1700 & 400 \\
\hline & 30 & 2660 & 2070 & 590 \\
& 31 & 2700 & 2100 & 600 \\
& 34 & 2850 & 2300 & 550 \\
& 33 & 2800 & 2300 & 500 \\
& 35 & 3050 & 2300 & 750 \\
\hline
\end{tabular}

Pengujian dengan jumlah minyak $2000 \mathrm{ml}$ dibutuhkan dengan rata-rata waktu selama 23 menit, Dengan total rata-rata pemisahan keseluruhan sebanyak $2164 \mathrm{ml}$, terdiri dari rata-rata $1740 \mathrm{ml}$ minyak dan $444 \mathrm{ml}$ air. Pengujian dengan jumlah minyak $2500 \mathrm{ml}$ dibutuhkan dengan rata-rata waktu selama 32,6 menit, Dengan total rata-rata pemisahan keseluruhan sebanyak $2812 \mathrm{ml}$, terdiri dari ratarata $2214 \mathrm{ml}$ minyak dan $598 \mathrm{ml}$ air.

Jumlah pemisahan yang tidak sesuai dengan jumlah yang diuji, hal ini disebabkan karena pemisahan terjadi apabila kondisi sensor sedang mendeteksi minyak, jika sensor tidak lagi mendeteksi minyak maka pemisahan akan berhenti, maka minyak terakhir yang dipompa akan tetap berada dalam bak pemisah.

Pada setiap peningkatan waktu pengujian terdapat perbedaan hasil pemisahan, pada awal pengujian didapatkan jumlah minyak lebih banyak dan jumlah air sedikit, pada hasil pengujian akhir jumlah minyak menurun dan jumlah air meningkat, hal ini disebabkan karena pada awal pengujian jumlah minyak masih banyak, sedangkan pada tahap akhir jumlah minyak sedikit.

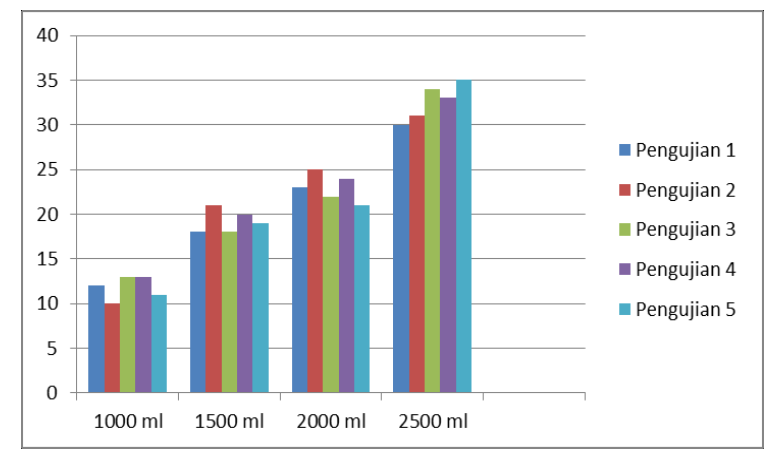

Gambar 3. Grafik perbandingan jumlah minyak terhadap waktu

Hasil pengujian pada setiap perbedaan jumlah minyak terhadap waktu pemisahan dapat dilihat pada Gambar 3, bahwa setiap perbedaan jumlah minyak yang diuji akan mempengaruhi waktu pemisahan dan hasil pemisahan. Peningkatan jumlah minyak akan mempengaruhi proses pemisahan akan semakin lama, karena semakin banyak jumlah minyak akan menghambat putaran pompa yang disebabkan oleh kekentalan minyak.

\section{Kesimpulan}

Hasil pengujian secara keseluruhan dihitung dengan angka rata-rata. 
1. Jumlah minyak yang diuji dengan jumlah minyak $1000 \mathrm{ml}$ dibutuhkan dengan rata-rata waktu selama 11,8 menit, total rata-rata pemisahan keseluruhan sebanyak $1142 \mathrm{ml}$, terdiri dari rata-rata $742 \mathrm{ml}$ minyak dan 400 $\mathrm{ml}$ air.

2. Pengujian dengan jumlah minyak $1500 \mathrm{ml}$ dibutuhkan dengan rata-rata waktu selama 19,2 menit, total rata-rata pemisahan keseluruhan sebanyak $1660 \mathrm{ml}$, terdiri dari rata-rata $1260 \mathrm{ml}$ minyak dan $400 \mathrm{ml}$ air.

3. Pengujian dengan jumlah minyak $2000 \mathrm{ml}$ dibutuhkan dengan rata-rata waktu selama 23 menit, dengan total rata-rata pemisahan keseluruhan sebanyak $2164 \mathrm{ml}$, terdiri dari rata-rata $1740 \mathrm{ml}$ minyak dan $444 \mathrm{ml}$ air.

4. Pengujian dengan jumlah minyak $2500 \mathrm{ml}$ dibutuhkan dengan rata-rata waktu selama 32,6 menit, dengan total rata-rata pemisahan keseluruhan sebanyak $2812 \mathrm{ml}$, terdiri dari rata-rata $2214 \mathrm{ml}$ minyak dan $598 \mathrm{ml}$ air.

\section{UCAPAN TERIMA KASIH}

Judul untuk ucapan terima kasih dan referensi tidak diberi nomor [10]. Terima kasih disampaikan kepada Tim Jurnal Sustainable yang telah meluangkan waktu untuk membuat template ini.

\section{REFERENSI}

[1] [1] Dahyat, A., 2016, Rancang Bangun Alat Pemisah Minyak Pelumas (Oli) dengan Air Secara Otomatis pada Limbah
Perbengkelan. Skripsi, Politeknik Negeri Padang, Padang.

[2] Haryanto, N.F., Prasetyawan, I.B., dan Marwoto, J. 2017, Pemodelan Tumpahan Minyak Di Perairan Teluk Lampung. Jurnal Oseanografi.

[3] Kuncowati, 2010, Pengaruh Pencemaran Minyak di Laut Terhadap Ekosistem Laut, Aplikasi Pelayaran dan Kepelabuhanan.

[4] Setiawan, T.E., Haeruddin., dan Ain, C., 2014,Efisiensi Penggunaan Oil Water Separator Pada Kapal Penangkap Ikan Untuk Pencegahan Pencemaran Minyak Di Laut (Studi Kasus Km. Mantis) Di Bbppi Semarang. Diponegoro Journal Of Maquares.

[5] Siagian, Y.S., Rifai, A., dan Ismanto, A., 2016, Pemodelan Sebaran Tumpahan Minyak Di Perairan Teluk Balikpapan, Kalimantan Timur, OSEANOGRAFI.

[6] Santosa, R.W., 2013, Dampak Pencemaran Lingkungan Laut Oleh Perusahaan Pertambangan Terhadap Nelayan Tradisional, Lex Administratum.

[7] Trianjaswati, dan Irma. 2013, Sensor Photodioda.www.unair.ac.id/artikel_detail84996-Sensor-sensor\%20photodioda.html

[8] Wikipedia bahasa Indonesia, Limbah Minyak, tanggal akses 10 Oktober 2020

[9] Supriyanto. 2017. Peran Dinas Lingkungan Hidup Dalam Menangani Masalah Limbah Minyak (Sludge Oil) Di Kabupaten Bintan. Universitas Maritim Raja Ali Haji 